Volume 3, Number 2, 2017

\title{
Model of Biomineralization of Ferrum Compounds by Gallionella Cells Immobilized on Contact Loading of Bioreactor
}

\author{
Oleksandr Kvartenko ${ }^{a, *}$, Iryna Gryuk ${ }^{b}$ Larysa Sabliy $^{c}$ \\ ${ }^{a}$ National University of Water Environmental Engineering, 11, Soborna St. Rivne, 33028, Ukraine \\ ${ }^{b}$ Rivne State Humanitarian University, 12, Stepana Bandery St., Rivne, 33028, Ukraine \\ "National Technical University of Ukraine "Igor Sikorsky Kyiv Polytechnic Institute", \\ 37, Peremohy Ave., Kyiv, 03056, Ukraine
}

Received: November 21, 2017. Revised: December 03, 2017. Accepted: December 06, 2017.

(c) 2017 The Authors. Published by Lviv Polytechnic National University.

\begin{abstract}
In the underground waters not polluted by organic compounds the bivalent iron occurs in the form of hydrocarbonates. An inseparable part of ferrum ions are ferrum bacteria. As a result of the literature review carried out it is determined that up till present no mechanism of the impact of additional source of non-organic carbon on the processes of in-cellular metabolism of Gallionella type bacteria had been established. The aim of the paper is the determination of the effect of the additional source of non-organic carbon in the form of $\mathrm{Na}_{2} \mathrm{CO}_{3}$ on processes of metabolism and the rate of biochemical oxidation of iron compounds by bacteria Gallionella sp. and the development of the possible mechanism of the assimilation of non-organic carbon in the recovered pentose phosphate cycle. The comprehensive scheme of activating bacteria metabolism developed by us testifies to the possibility of increasing the energy capacity of recovered pentose phosphate cycle, the acceleration of metabolism cycles and the rate of pumping electrons via the fermentative cell system. The totality of presented processes results in speeding up the fermentative oxidation of $\mathrm{Fe}^{2+}$ on the surface of a cell with the final formation of matrix structures of biominerals and the increased efficiency of bioreactors operation.
\end{abstract}

Keywords: biomineralization of iron compounds; iron bacteria; electrons; respiratory chain.

\section{Introduction}

In the underground waters non-polluted by organic compounds the bivalent iron occurs, as a rule, in the form of hydrocarbonates. In non-oxidized underground waters iron ions (II) are subjected to hydrolysis with the formation of complexes:

$$
\begin{gathered}
\mathrm{Fe}^{2+}+\mathrm{OH}^{-}=\mathrm{FeOH}^{+} ; \\
\mathrm{Fe}^{2+}+2 \mathrm{OH}^{-}=\mathrm{Fe}(\mathrm{OH})_{2} .
\end{gathered}
$$

An inseparable component of ferrum ions in underground waters are various kinds of iron and of manganum oxidizing bacteria. The presence of these or other kinds of iron bacteria depends on a number of factors. The main ones include the level of $\mathrm{pH}$ - Eh of the medium, the availability of dissolved organics or of mineral

${ }^{*}$ Corresponding author. Email address: o.m.kvartenko@nuwm.edu.ua

This paper should be cited as: O. Kvartenko, I. Gryuk, L. Sabliy. Model of biomineralization of ferrum compounds by Gallionella cells immobilized on contact loading of bioreactor. Energy Eng. Control Syst., 2017, Vol. 3, No. 2, pp. 51 - 56. https://doi.org/10.23939/jeecs2017.02.051 
carbon, and also the presence of $\mathrm{Fe}^{2+}$ ions. In acid waters with $\mathrm{pH}=3.5-5.0$ the development of Th.ferroidans bacteria is observed. In waters with the $\mathrm{pH}$ level $=5.5-7.5$ and $\mathrm{Eh}=100-300 \mathrm{mB}$ there are Gallionella gram negative chemo-litho-autotrophs the energy source for which is a non-organic carbon contained in the form of free carbon dioxide or hydrocarbonates. Bacteria of this type develop in microaerophile conditions with the concentration of dissolved oxygen from 0.1 to $3.0 \mathrm{mg} / \mathrm{dm}^{3}$ with $\mathrm{t}=8-16^{\circ} \mathrm{C}$ and concentration of $\mathrm{Fe}^{2+}$ from 1.0 to $30 \mathrm{mg} / \mathrm{dm}^{3}$.

In waters with the $\mathrm{pH}$ level $=6.0-7.5$, under anoxide conditions with the concentration of oxygen $1.0-3.0$ $\mathrm{mg} / \mathrm{dm}^{3}, \mathrm{t}=10-40{ }^{\circ} \mathrm{C}$, there is observed the active development of gram negative heterotrophic bacteria of Lephothrix type. The concentration of dissolved oxygen for this type of bacteria is not a limiting factor. The oxidation of ferrum by these bacteria is not connected with receiving energy but is a consequence of the oxidization by products of their in-cellular metabolism - by hydrogen peroxide. The source of carbon is organic acids and sugar. Bacteria of Lephothrix type are able to develop under the conditions of the pollution of underground waters by dissolved humin acids. The works by Czekalla, 1985; Seppänen H. 1991; Mouchet, 1992; Mencha M. N., 2000; Zhurba M.G., 2006; [1 - 5] are dedicated to studying possibilities of using iron bacteria in the branch of treating underground waters.

However, most of them study only the natural mechanism of the iron compounds oxidation with the help of various types of iron bacteria $[1,2,4]$, and also optimal values of dissolved oxygen, $\mathrm{pH}$ - Eh values of medium [2, $3,5]$, of the rate of filtering in bioreactors with permanent water consumption [3,5].

Up till present, there had been no studies of the optimal value of bicarbonate alkalinity of outlet water, and also of using the additional source of non-organic carbon of Gallionella chemo-litho-autotrophs. Thus, an urgent task is the disclosure of the effect of the additional source of non-organic carbon on processes of mass transfer, rate of biochemical oxidation of ferrum compounds and the development of the mechanism for assimilating non-organic carbon into recovered pentose phosphate cycle exemplified by Gallionella bacteria.

\section{Analysis of recent publications and research}

At present, several mechanisms are known which describe the movement of electrons along the breathing chain of chemo-litho-autotrophs of bacteria. Fig.1 presents the mechanism of the electrons transport in the breathing chain of chemo-litho-autotrophic ferrum bacteria [6].

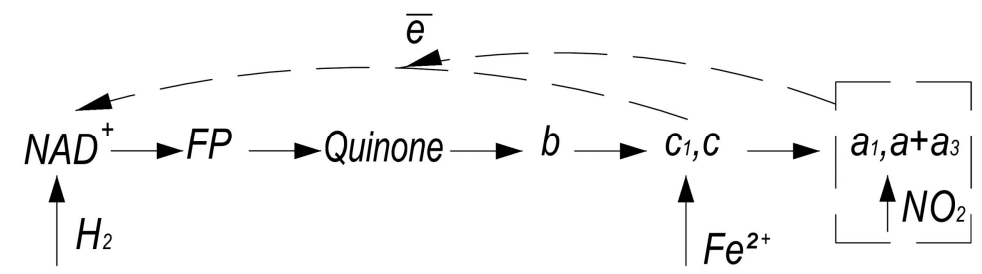

Fig.1. Scheme of electrons movement for aerobic chemo-litho-autotrophic iron bacteria [6].

As a result of the wide spectrum of research concerning physiology, genomics and systematics of fresh water ferrum bacteria conducted by a group of scientists under the guidance of David Emerson, Eric Field and Caren Davenport in Bigelow Laboratory for Ocean Sciences, in East Boothley Harbor, in Los Alamos National Laboratory, in DOE Joint Denome Institute, in Walnut Creek, USA the improved scheme was suggested of the transport of electrons from $\mathrm{Fe}^{2+}$ ions, in cyto-plasmatic membrane of ferrum bacteria Gallionella (Fig. 2).

The scheme is based only on genomic analysis $\mathrm{Mt}_{0} \mathrm{~A}$ and shows the possibility of protein to initiate to initiate the oxidation of $\mathrm{Fe}^{2+}$ to $\mathrm{Fe}^{3+}$. In work [7] it is shown that the mechanism of electrons transport from the exterior cell of membrane to cytoplasma is still unknown. As a result of studies [7] is determined that bacteria of Gallionella ES-2 type have no $b c_{l}$ chrosomes and it was assumed that ACIII pool may substitute their functions. The organism has $b d$ type of cytochrome oxidase, which may interact with quinones. According to Emerson researches the chain of electrons movement consists of five separate complexes [8]. Gallionella orgamism is fully completed with genomes for NADH of dehydrogenaze, and also with complex of dehydrogenaze succinate (Fig.2). 


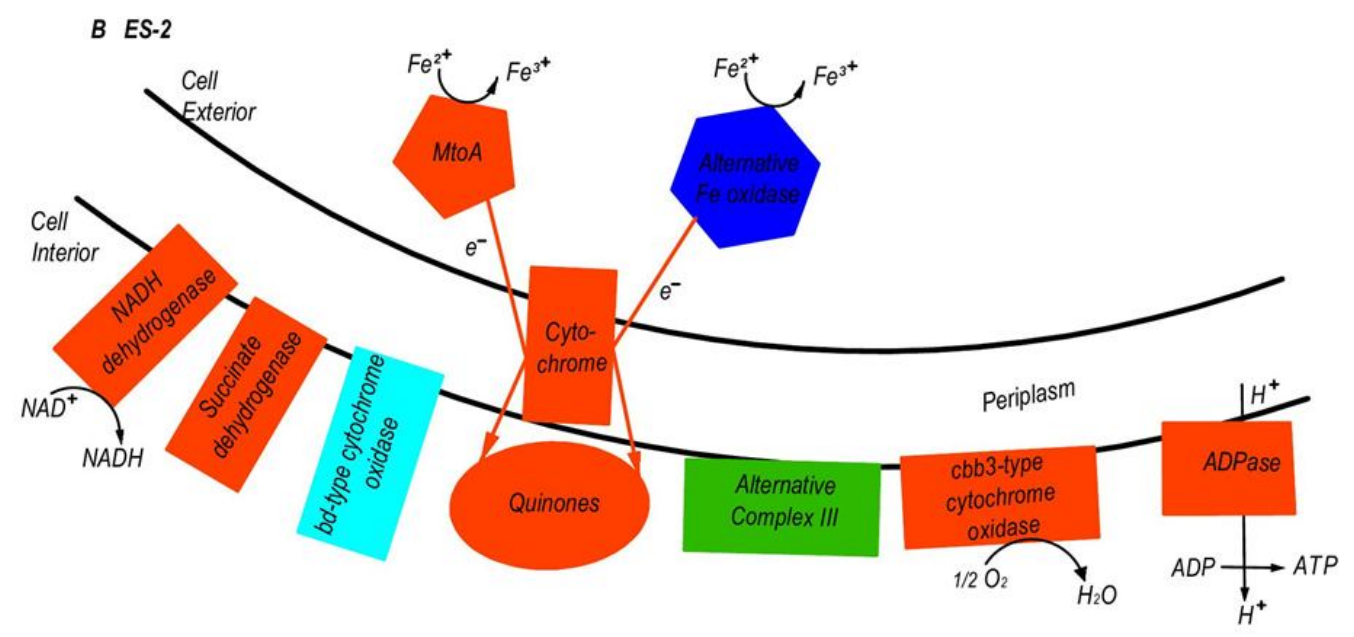

Fig.2. Scheme of electron motion from $\mathrm{Fe}^{2+}$ ions to the respiratory chain at the Gallionella CPM [7].

The microrganism has quinon with the help of which the splitting off and the transfer of the electron from NADH dehydrogenaze to cytochrome complex ACIII takes place. As was noted down in papers [7,8] the microorganism has a cluster which includes molybdopterin oxidoreductase. This [ACIII] complex is able to interact with pools of quinions and movements of electrons to the terminal of oxidaze [9] as a result of which a microorganism is able to use it instead of cytochrome $b c_{1}$ complex. The microorganism has also cytochrome of $c b b_{3}$ oxidaze which have larger inclination for oxygen [10]. Besides, the microorganism codes cytochrome of $b d$-oxidaze which is also the inclination for normal development in the conditions for the presence of oxygen and is connected directly with quinion pool [11].

Ferrum bacteria of Gallionella type are well adapted to chemolithoautotropy, including the assimilation of $\mathrm{CO}_{2}$ and have the system of electrons transport adapted for their development in the medium with low concentrations of oxygen. Correspondingly to [7] Gallionella contain additional genes for producing polysaccharide and for fixing $\mathrm{CO}_{2}$, and also are adapted to the action of heavy metals.

\section{Forming paper aim}

The aim of theoretical researches was to reveal the impact of the additional source of non-organic carbon in the form of $\mathrm{Na}_{2} \mathrm{CO}_{3}$ on processes of mass transfer and rate of biochemical oxidation of ferrum compounds into Gallionella sp. The development of the possible mechanism of the assimilatio of nonorganic carbon with $\mathrm{Na}_{2} \mathrm{CO}_{3}$ in recovered pentose phosphate cycle.

\section{Presentation and discussion of research results}

On the basis of the theory of electrons movement mechanism from $\mathrm{Fe}^{2+}$ ions to breathing mechanism on cytoplasmic membrane ferrum bacteria of Gallionella type [7] we for the first time suggested the mechanism for activating processes of electron transport, the assimilation of carbon dioxide, the operation of proton cellular pump in ferrum bacteria of Gallionella type with removing products of hydrolysis outside the boundaries of reaction in bioreactors while using the additional source of carbon in the form of calcinated soda (Fig.3).

In underground waters iron is contained in the presence of $\mathrm{HCO}_{3}{ }^{-}$ions both in the form of $\mathrm{Fe}{ }^{2+}, \mathrm{Fe}(\mathrm{OH})^{+}$and in the molecular form of $\mathrm{Fe}(\mathrm{OH})_{2}$. Under the insufficient quantity of dissolved oxygen in water and the presence of other reducers the oxidation of ferrum compounds (II) is preceded by hydrolysis.

$$
\begin{gathered}
\mathrm{Fe}^{2+}+2 \mathrm{HCO}_{3}^{-}+2 \mathrm{H}_{2} \mathrm{O} \leftrightarrow \mathrm{Fe}(\mathrm{OH})_{2}+2\left[\mathrm{CO}_{2}+\mathrm{H}_{2} \mathrm{O}\right] \\
\mathrm{Fe}^{2+}+2 \mathrm{HCO}_{3}^{-} \stackrel{\mathrm{H}_{2} \mathrm{O}}{\leftrightarrow} \mathrm{Fe}(\mathrm{OH})_{2}+2 \mathrm{CO}_{2} ; \\
\mathrm{Fe}^{2^{+}} \stackrel{\mathrm{H}_{2} \mathrm{O}}{\mathrm{H}^{+}} \mathrm{FeOH} \stackrel{\mathrm{H}_{2} \mathrm{O}}{\mathrm{H}_{+}^{+}} \mathrm{Fe}(\mathrm{OH})_{2}
\end{gathered}
$$


Therefore, in the block "source waters" (fig.3) two processes connected with the gydrolysis of ferrum compounds are simultaneously considered. I - hydrolysis of ferrum hydrocarbonate $\mathrm{Fe}\left(\mathrm{HCO}_{3}\right)_{2}$, with formation of $\mathrm{Fe}(\mathrm{OH})_{2}$ and two molecules of $\mathrm{CO}_{2}$. II - hydrolysis of the small quantity of $\mathrm{Fe}^{2+}$ ions with the formation of $\mathrm{FeOH}$ $\rightarrow \mathrm{Fe}(\mathrm{OH})_{2}$ and the removal of two protons which acidize water. This process is simplified (without the influence of dissolved organic substances, sulfides and hydrosulfides) and presented in Fig.3 in block "source water".

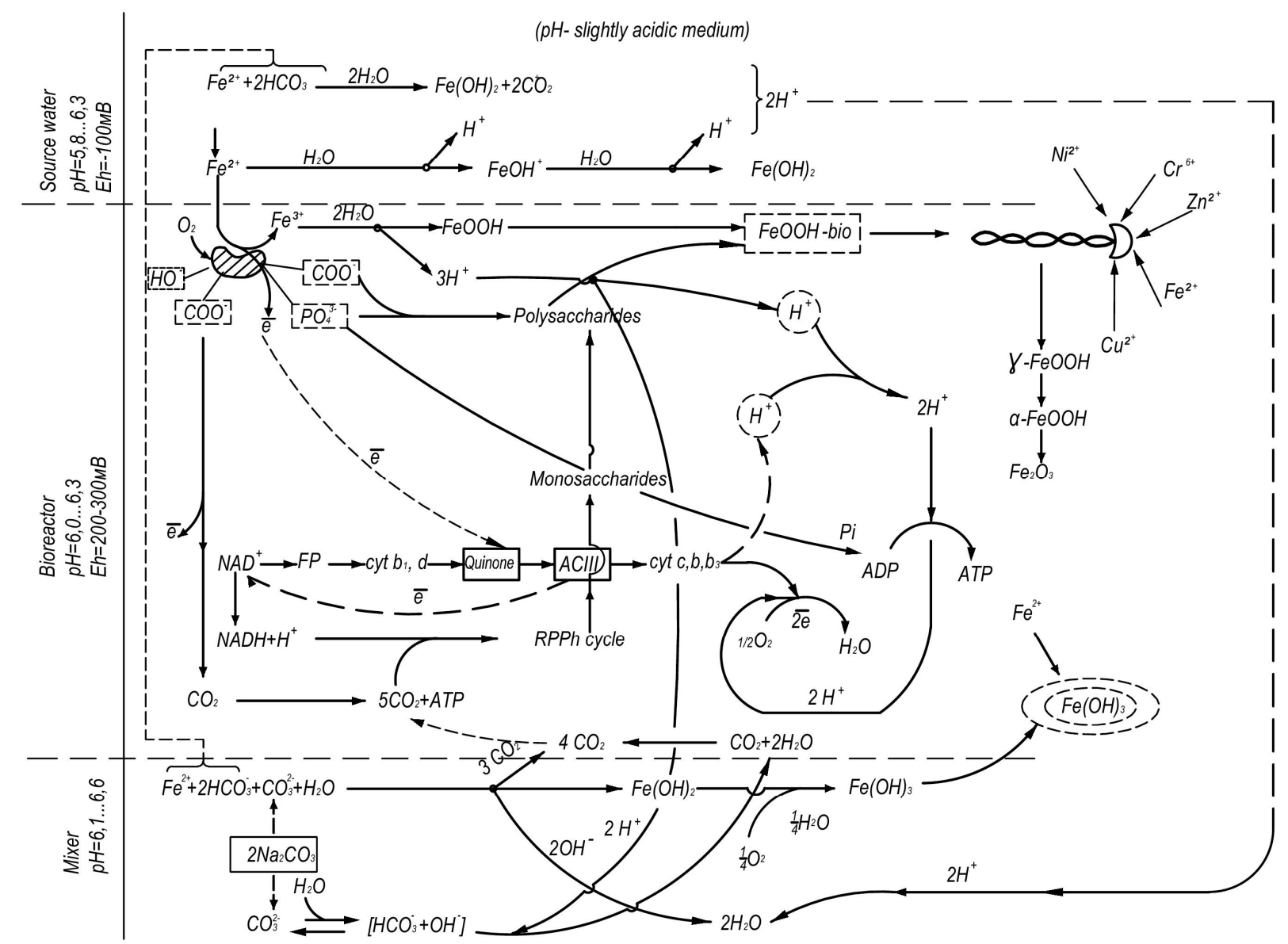

Fig.3. The complex scheme of activation of processes of intracellular metabolism of bacteria Gallionella, fixed on contact loading of a bioreactor using the additional source of carbon in the form of calcinated soda.

In the mixer, there tales place the stage by stage introduction into the source water of the solution of calcinated soda and air oxygen. In soda solution introduction, there takes place the hydrolysis of $\mathrm{Na}_{2} \mathrm{CO}_{3}$ by anion with the formation of two molecules $\mathrm{CO}_{2}$ and two molecules of ions hydroxide which neutralize two protons created in outlet water as a result of the hydrolysis of $\mathrm{Fe}^{2+}$ and which are removed as water from the zone of reaction:

$$
\begin{gathered}
2 \mathrm{HCO}_{3}^{2-}+2 \mathrm{H}^{+} \mathrm{OH}^{-} \rightarrow 2\left[\mathrm{H}_{2} \mathrm{O}+\mathrm{CO}_{2}\right]+2 \mathrm{OH}^{-} \\
2 \mathrm{OH}^{-}+2 \mathrm{H}^{+}=2 \mathrm{H}_{2} \mathrm{O}
\end{gathered}
$$

When introducing the calculated concentration of dissolved oxygen $1 / 4 \mathrm{O}_{2}$ there takes place the oxidation of the part of ferrum compounds (II) to ferrum hydrooxides (III) with their removal outside the boundaries of the zone of the biological process of treatment. When introducing calcinated soda, there takes place the increase in $\mathrm{pH}$ and the biocarbonate alkalinity of the medium, the speeding up of the processes of hydrolysis. Simultaneously with this, the removal of products of hydrolysis from the zone of reaction contributes to more complete formation of $\mathrm{Fe}(\mathrm{OH})_{3}$ in the mixer. Carbon which is introduced at this stage to mixer, is an additional source for building cellular material, along with hydrocarbonates and carbon dioxide of source water. Carbon is built-in to the recovered pentose phosphate cycle 
as a result of which monosacharides are formed which later on are able to being polymerized into polysacharides complexes with fermentative oxidation on the surface of a cell by $\mathrm{Fe}^{2+}$ ion transforming into biominerals $\mathrm{FeOOH}$-bio [12], which have a characteristic form of spiral-like stems of Gallionella iron bacteria.

The presence of which, in matrix structures of interporous space of contact loading of bioreactors, was confirmed by results of researches carried out at stations of biological deferrization in a settlement of Rokytne and t. Berezne of Rivne region [13]. The spectral analysis of bacteria covers, carried out with the help of a raster-type microscope FEI Quanta (USA) equipped with Roentgen spectroscope for conducting the microanalysis (EDAX), showed the presence of not only of $\mathrm{Fe}$, but also of such elements as $\mathrm{C}, \mathrm{N}, \mathrm{P}$, which testifies about their biological origin [13].

Characteristic is the availability of negatively charged groups of anions $\mathrm{COO}^{-}, \mathrm{PO}_{4}{ }^{3-}, \mathrm{OH}^{-}$on the surface of a cell on which the adsorption takes place of ions $\mathrm{Fe}^{2+}$ [14]. Assimilated on the surface of a cell anions groups $\mathrm{COO}^{-}, \mathrm{PO}_{4}{ }^{3-}$ are used by a cell in subsequent cycles: phosphate non-organic $P_{\mathrm{i}}\left(\mathrm{PO}_{4}{ }^{3-}\right)$ is utilized in cycle ADP - ATP; carbinateion $\mathrm{COO}^{-}$is in the role of one of carbonate sources in cycles of building poysacharides, and also in recovered pentose phosphate cycle during electron loss and restoration to free form of carbon dioxide $\mathrm{CO}_{2}$.

Larger part of ions $\mathrm{Fe}^{2+}$ is tied via exterior cellular ferment - restuzian, losing one electron which is transported from the surface of the ferment to chinon and further transferred to complex AC III from where by the known scheme of back transport [7] a part of electrons against gradient is transferred to complex $\mathrm{NAD}^{+} \rightarrow \mathrm{NADH}+\mathrm{H}^{+}$and introduces together with carbon to the first stage of Calvin cycle. The higher is the value $\Delta \mu_{\mathrm{H}}{ }^{+}$, the quicker will be the process of pumping electrons from complex ACIII to complex $\mathrm{NAD}^{+}$with formation $\mathrm{NADH}+\mathrm{H}^{+}$as a result of which on the surface of a cell under the impact of polysacharides takes place the speeding up of hydrolysis processes of ions $\mathrm{Fe}^{3+}$ with the formation of matrices of biominerals which in time undergo the chain of transformations. Thus, the process of fermentative oxidation of ions $\mathrm{Fe}^{2+}$ takes place on the account of the transfer and building-in of the electron into the breathing chain of a bacterium. As a result the reaction of biochemical transformation $\mathrm{Fe}^{3+} \rightarrow \gamma \mathrm{FeOOH}$ takes place with the removal into the environment of three protons, two of each are tied with complex $\left[\mathrm{HCO}_{3}{ }^{-}+\mathrm{OH}^{-}\right]$created as a result of the hydrolysis of one of molecules of calcinated soda in the mixer as a result of which an additional molecule of carbon dioxide comes into the bioreactor. Besides, another three molecules of carbon dioxide formed as a result of the hydrolysis of ferrum hydrocarbonate and calcinated soda come into the bioreactor from the mixer. Another molecule of carbon dioxide from carboxylate-ion $\mathrm{COO}^{-}$(Fig.3) joins these molecules in the bioreactor. Thus, a pool is created from five molecules of carbon dioxide which are assimilated by a cell at the first stage of recovered pentose phosphate cycle with stage-by-stage formation of mono- and polysacharides.

As was pointed down earlier, as a result of the hydrolysis of ions $\mathrm{Fe}^{3+}$ as a consequence of fermentative reactions three protons are created two of which are neutralized by a complex $\left[\mathrm{HCO}_{3}{ }^{-}+\mathrm{OH}^{-}\right]$with the formation of $\mathrm{CO}_{2}$ and two molecules of water. A proton which remained together with the proton singled out by a cell in the process of breathing uses a cellular proton pump for transferring into the cycle the creation ATP of the number of protons in the environment of a cell decreases, and a proton freed as a result of the reaction hydrolysis of $\mathrm{Fe}^{3+}$ is transferred to the free place. Thus, the speeding up of the process of hydrolysis of ions $\mathrm{Fe}^{3+}$ takes place in the presence of polysacharides with the formation of matrix structure of biominerals.

\section{Conclusion}

Based on the consideration of the presented mechanism, we can see that after introducing the additional source of non-organic carbon, the energy capacity of recovered pentose phosphate cycle increases, cycles of in-cellular metabolism and the rate of electrons pumping via exterior fermentative system of a cell are accelerated. The totality of presented processes results in speeding up the fermentative oxidation of ions $\mathrm{Fe}^{2+}$ on the surface of a cell with the final formation of matrix structures of biominerals. The presented scheme shows the balancing of the process of the biochemical oxidation of $\mathrm{Fe}^{2+}$ by ferrum bacteria of Gallionella type at once in three directions: first - the arrival of $\mathrm{H}^{+}$to proton pump with the formation of ATP; second - the creation of polysacharides, via recovered pentose phosphate cycle as a result of the supply of the additional source of carbon; third - the acceleration of "pumping" electrons with the help of the restucian ferment.

\section{References}

[1] Czekalla, C. (1985). Quantitative Removal of Iron and Manganese by Microorganisms in Rapid Sand Filters (In Situ Investigations) / C. Czekalla, W. Mevius, H. Hanert // Water Supply. - vol. 3. - Berlin “B”, pp. 111-123.

[2] Seppänen H. (1991). Experiences of Biological iron and manganese removal in Finland. / H.Seppänen// Proc. IWEM ann. Sym. - no 15(1). p. 9-11. 
[3] Mouchet, P. (1992). From Conventional to Biological Removal of Iron and Manganese in France/ P. Mouchet,// Journal of the American Water Works Association. - 1992 - vol. 84, no 4, p. 158-167.

[4] Mencha M. N. (2006). Ferrobacteria in water supply systems with underground water sources. / M.N. Mencha// Water Supply and Sanitary Engineering. - No. 7. p. 25-32. (in Russian)

[5] Zhurba M.G. (2006). Biochemical deironing and demanganation of underground water / M.G.Zhurba, Zh.M. Govorova., A.N.Kvartenko, O. B. Govorov // Water Supply and Sanitary Engineering.- No. 9., part 2. pp. 17-23. (in Russian)

[6] Gusev M.V., Mineeva L.A. (2003). Microbiology. Textbook. M .: Academy, -464 p. (in Russian)

[7] Emerson D., Field E., Chertkov O., Davenport K. W., Goodwin L., Munk C., Nolan M., Woyke T. (2013). Comparative genomics of freshwater Fe-oxidizing bacteria: implications for physiology, ecology, and systematics. Frontiers in Microbiology / Evolutionary and Genomic Microbiology. Volume 4 | Article 254. doi: 10.3389/fmicb.2013.00254.

[8] Nicholls, D. G., and Ferguson, S J. (2002). Bioenergetics 3.London: Academic Press.

[9] Refojo,P.N.,Teixeira,M.,and Pereira, M. M. (2012). The alternative complex III: properties and possible mechanisms for electron transfer and energy conservation. Biochim. Biophys. Acta 1817, 1852-1859. doi:10.1016/j.bbabio.2012.05.003

[10] Gennis, R. B., and Stewart, V. (1996). "Respiration," in Escherichia coli and Salmonella Cellular and Molecular.

[11] Borisov, V. B., Gennis, R. B., Hemp, J., and Verkhovsky, M. I. (2011). The cytochrome bd respiratory oxygen reductases. Biochim. Biophys. Acta 1807, 1398-1413. doi: 10.1016/j.bbabio.2011.06.016.

[12] Hallberg R., Ferris, F Grant (2004). Biomineralization by Gallionella. Geomicrobiology Journal. Vol. 21, P. 325-330.

[13] Kvartenko A., Orlov V., Pletuk O. (2016). Research into the biosorption process of heavy metal ions by the sediments from stations of biological iron removal. Eastern-European Journal of Enterprise Technologies. Vol. 4, No. 10 (88), p. 37 - 43.

[14] Bukreeva V.Yu., Grabovich M.Yu., Eprintsev A.T., Dubinina G.A. (2009). Sorption of colloidal compounds of iron and manganese oxides by means of iron bacteria on sandy loads of treatment facilities of water-lifting stations. / Sorption and chromatographic processes. - V. 9. Iss. 4. P. 506 - 514. (in Russian)

\title{
Модель біомінералізації сполук заліза клітинами Gallionella, іммобілізованими на контактному завантаженні біореактора
}

\author{
Олександр Квартенко ${ }^{a}$, Ірина Грюк ${ }^{b}$, Лариса Саблій $^{c}$ \\ ${ }^{a}$ Національний університет водного господарства та природокористування, \\ вул. Соборна 11, м. Рівне,33028, Україна \\ ${ }^{b}$ Рівненський державний гуманітарний університет, вул. Степана Бандери, 12, Рівне, 33028, Україна \\ ${ }^{c}$ Наиіональний технічний університет Украйни «Київський політехнічний інститут імені Ігоря Сікорського», \\ Солом'янський район, пр-т Перемоги, 37 , Київ, 03056, Украӥна
}

\begin{abstract}
Анотація
У підземних водах, незабруднених органічними сполуками, двовалентне залізо зустрічається у формі гідрокарбонатів. Невід'ємним супутником іонів заліза $є$ залізобактерії. В результаті проведеного літературного огляду встановлено, що до теперішнього часу не було вивчено механізми впливу додаткового джерела неорганічного вуглецю на процеси внутрішньоклітинного метаболізму бактерій роду Gallionella. Метою роботи $\epsilon$ встановлення впливу додаткового джерела неорганічного вуглецю у вигляді $\mathrm{Na}_{2} \mathrm{CO}_{3}$ на процеси масообміну та швидкість біохімічного окиснення сполук заліза бактеріями Gallionella sp. та розробка можливого механізму асиміляції неорганічного вуглецю до відновленого пентозофосфатного циклу. Розроблена нами комплексна схема активації метаболізму бактерій свідчить про можливість підвищення енергетичної потужності відновленого пентозофосфатного циклу, прискорення циклів метаболізму та швидкості перекачування електронів через ферментативну систему клітини. Сукупність наведених процесів призводить до прискорення ферментативного окиснення іонів $\mathrm{Fe}^{2+}$ на поверхні клітини 3 кінцевим утворенням матриксних структур біомінералів та підвищення ефективності роботи біореакторів.
\end{abstract}

Ключові слова: біомінералізація сполук заліза; залізобактерії; електрони; дихальний ланцюг. 